Document downloaded from:

http://hdl.handle.net/10251/179809

This paper must be cited as:

Orero-Blat, M.; Botella-Carrubi, D.; Simón-Moya, V.; Sendra, J.; Mogorrón Guerrero, H. (2020). Client orientation in fashion e-commerce: a comparative study. IEEE. 1-6. https://doi.org/10.23919/CISTI49556.2020.9141057

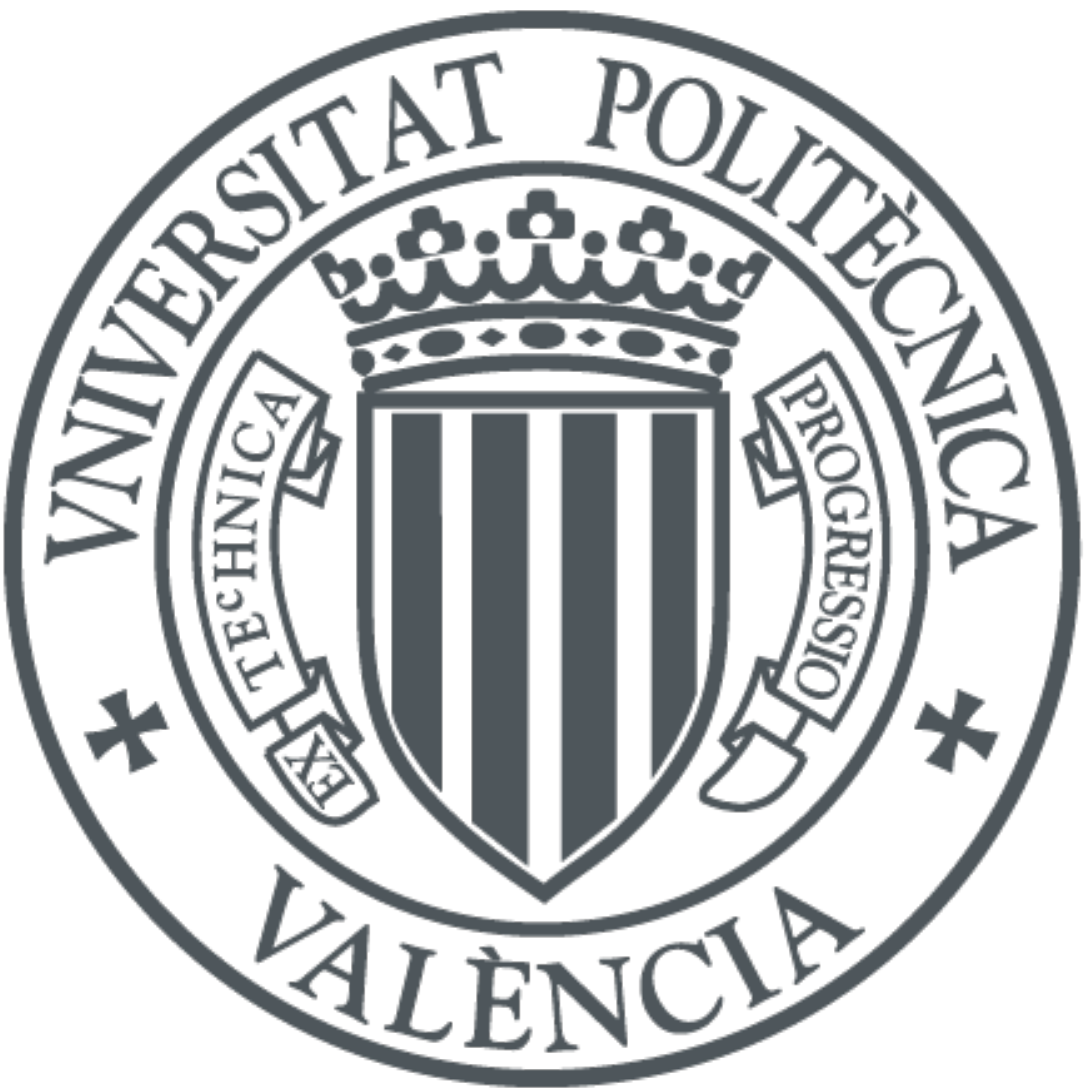

The final publication is available at

https://doi.org/10.23919/CISTI49556.2020.9141057

Copyright IEEE

Additional Information 


\section{Client orientation in fashion e-commerce: a comparative study}

\author{
Maria Orero-Blat \\ Department of Business Organization \\ Universitat Politècnica de València \\ Valencia, Spain \\ morebla@doctor.upv.es \\ Virginia Simón-Moya \\ Department of Business Administration \\ Universitat de València \\ virginia.simon@uv.es \\ Helena Mogorrón Guerrero \\ Department of Business Organization \\ Universitat de València \\ Valencia, Spain \\ Helena.mogorron@ext.uv.es
}

\begin{abstract}
E-business and especially e-commerce represents one of the most important ways of doing business in the current context. That is why, researchers are doing a great effort in studying how B2C platforms manage the relationship with their clients. Regarding the most important channels of connection between consumers and companies in online market, the websites and Apps, this study analyzes the way in which e-businesses present the information to their clients from a client-focused strategy point of view. The present study evaluates how two important e-commerce companies deal with this in such a competitive market as fashion.
\end{abstract}

Keywords - e-commerce; e-business; fashion; client orientation.

\section{INTRODUCTION}

Business model evolution is a key fact that has reshaped different sectors during the last fifteen years. The global financial crisis and globalization resulted in a massive close of local stores and expansion of e-business and e-commerce [1].

Fashion sector is one of the most profitable industries nowadays [2] and has also been transformed thanks to e-commerce, shifting most of total turnover to online platforms instead of physical stores [3] Currently, each company which prevails over the rest in creating value for customers should present a sustainable business model [4].

According to the e-business marketing consultancy eMarketer [5], worldwide retail e-commerce experiments currently a continuous increment. By the end of 2021 it is expected to generate $\$ 4.48$ trillion, whilst $\$ 2.29$ trillion were generated in 2017. That is why, e-commerce represents nowadays a great field of study for management researchers. About it, literature

\author{
Dolores Botella Carrubi \\ Department of Business Administration \\ Universitat Politècnica de València \\ dbotella@omp.upv.es \\ Javier Sendra \\ Department of Business Administration \\ Universidad Complutense de Madrid \\ Javier.68.sendra@gmail.com
}

of e-commerce is extensively focused on value chain and especially on the relationship between providers and ecommerce platforms, or what is known as business to business or B2B (see for example Kotler and Pfoertsch, 2006), which is in part due to the great importance of supply chain on ecommerce [6].

Further, the type of e-commerce done between the ecommerce and the final consumer or B2C is based on research on the consumer trust towards the company. However, little is known about the client orientation strategy in terms of the main communication channel, the webpage. For this reason, the main objective of this research is to evaluate how a clientorientation strategy is the key basis of the competitive advantage of an e-commerce.

Further, due to the great importance of the fashion sector in ecommerce [7], this paper sheds light on the strategies undertaken to compete in the online fashion sector. In order to do so, the methodology of the case study will be employed, analysing the strategy and functioning of two successful fashion e-commerces in a comparative study.

This paper contains a descriptive and comparative study between two fashion successful e-commerces: Zalando and Mytheresa, which lead the retail sector in Europe, focusing each one in one type of target customers and demonstrating an outstanding client-oriented strategy.

The structure of the present study will be the following: after this introduction, a theoretical framework on the topic will be 
developed. Literature about e-business models and e-commerce will be discussed, the fashion sector in the European market commented and then the client-orientation strategy types will be explained. Afterwards, the case study and comparative analysis methodology will be shortly commented. To conclude with, the results of this descriptive analysis will be presented and discussed, in order to analyse the similarities and differences between them according its way to compete.

\section{THEORETICAL FRAMEWORK}

\section{A. E-business models and B2C}

Electronic business or e-business refers to the business that is conducted over the internet [8]. That is, the e-business bases its relationships with customers, suppliers or even partners on the use of internet technologies "to share information, process transactions, coordinate activities, and facilitate collaboration" [9]

One of the most common types of e-business is the one that uses the internet to establish the relationship between the company and the customer, what is called business to consumer or B2C [10]. In the last six years (from 2014 to 2019), this type of e-business has grown worldwide more than a $200 \%$ and has passed from being 1.34 to 3.53 trillion US dollars [11]. Further, the forecast by 2023 is more than 6 trillion US dollars [11].

Therefore, due to this context of growth companies are doing an effort to incorporate the B2C model in order to compete. Sometimes, this incorporation is done in ventures that were already established and which business model was not necessarily linked to the internet. In other cases, the B2C model has been the base of the business since the very beginning, influencing in this way the entrepreneurial development [12].

One of the most important sectors in B2C is fashion. Indeed, in 2018 , the $57 \%$ of the global electronic commerce was linked to fashion-related products [11].

In Europe, the electronic commerce of fashion is expected to grow to more than 95,000 million U.S. dollars in 2024, and [11]. For this reason, multiple associations are trying to push European institutions to regularize and legislate on ecommerce. One of the main associations regarding these goals of regularization and legislation on e-commerce issues is Ecommerce Europe. This association includes more than 100,000 European companies dedicated to the sale of products in the online market and its main goal is to help legislators to "create a better framework for online merchants, so that their sales can grow further" [13]. One of its last requests is linked to the proposition of the European Comission of an EU regulation on transparency and fairness in e-commerce. In doing so, the aforementioned association has developed an "E-commerce Europe position paper" in which the main figure to protect in online market is the client [13].

Thus, aware of the importance of client, e-commerce platforms are developing a set of practices and strategies in which the main focus is on customer perceptions and sale motivations.

\section{B. Client-focused strategies in fashion \& retail e-commerce}

As commented before, and even fashion industry is one of the leaders of the modern world in terms of profitability, it currently faces some challenges regarding its client orientation strategy and business culture [14].

The customer orientation may be defined as a strategy that allows firms to obtain and integrate the information that is necessary to develop and perform different marketing strategies in order to achieve more favorable customer results. This plan is highly focused in assuming that the firms with a customeroriented strategy outperform the competence, and its main base is the anticipation to the future customer's needs, in order to implement them in their products or by developing goods and services that satisfy them [15].

The main goals of a client-focused strategy are the increment of customer satisfaction and perceived value [16]. Satisfaction refers to the degree of alignment of customer expectations, while exceeding them after the experience of buying and using the products offered by the brand, and is a key feature for community engagement and loyalty [17]. On the other hand, the perceived value is defined as a marketing metric which measures the tradeoff between perceived benefits and perceived costs of the offered portfolio [18].

When analysing the competitive advantage of a company, marketing capabilities of the enterprise should be studied in order to evaluate their market-sensing capacity [19]. This fact is even more relevant when the competitive advantage of an enterprise relies on its client-orientation.

According Kumar and Pradhan [20], social media marketing is an outstanding method for communicating with clients and receiving their feedback. It plays an important role in all clientfocused strategies because of the opportunity that it gives to the companies for branding and reputation management [21]. It is defined as the marketing strategy that attracts and influences positively customers' purchase behaviour though the use of social networks [22].

With customer relationship management companies get closer to clients and offer them a suitable support along the sales funnel [23]. Furthermore, the tone and relationship with clients should be considered: it is important to take into account that a confident a reliable tone is needed in order to engage a community in social network [24].

Moreover, with the data generated from previous purchases, the companies make recommendations to their clients that reflect their purchase intention [25], generating for the e-commerce a type of specific knowledge about its clients [26]. The 
procurement of market information is an important ability that e-businesses should develop in order to their leading position [27]. Afterwards the analysis of quality, perceived value and satisfaction is relevant for customer relationship management in order to understand client perceptions and enhance offered value [28].

However, client-focused strategies vary regarding the target customer of the company. For this case, some components of the communication strategies in luxury fashion brands have been identified [29]: design signature, exclusivity, premium price, tailored marketing and communications and high-quality customer service are the outstanding ones.

\section{METHODOLOGY}

\section{A. Case studies and the comparative analysis}

The chosen methodology for addressing this proposed research has been the qualitative one. The authors have conducted a comparative analysis of two case studies with the aim to explore fenomena about which there is limited knowledge.

In order to analyse the client orientation strategy of the fashion e-commerce platforms, two case studies will be examined. Zalando and Mytheresa are the chosen ones, because of its rapid growth, international presence, success in retail online industry and customer-centered strategy in its reputation in social networks. Despite of its similitudes, these two companies present important differences in its target customer and its marketing strategy that should be outstanded.

\section{B. Data Collection}

Some part of the analyzed data was collected directly from the corporate webpages of two fashion enterprises. Moreover, in order to triangulate the information retrieved from the webpages, two open interviews were conducted to marketing employees of both companies.

\section{RESULTS}

\section{A. Zalando}

Zalando is the leading online fashion platform in the European market. It was founded in 2008, in Berlin, and was gradually positioning itself as a leading e-business of the fashion and retail sector. Their global sales reached 5.4 billion in 2018 [30]

They operate in different business areas, due to their flexibility and online nature. They use their logistics strategy to offer a fast service to multiple customers from their sales platform. Its business model consists of positioning and selling online fashion items (clothes, shoes, accessories and jewelry mainly) previously purchased from different partners (more than 2000 worldwide). These are from private brands to retail stores, and they also have an own fashion brand. This selection of items is adapted according to the preferences and needs of local customers, since they operate in 17 countries around the world and marketing is customised in each region. Their mission could be simplified in bring international fashion closer wherever the customer is.

The company has 14,000 employees distributed throughout Europe and its sales platform reaches around 300,000 visits monthly. Zalando enjoys a great brand awareness in Europe, especially among women from 25 to 40 years of middle class. As a basis for their success strategy, in addition to optimizing the distribution and logistics chain, they place the customer. Increasing the range of services offered to customers is their priority and the basis of their competitive strategy.

\section{B. Mytheresa}

Mytheresa is the most reliable online platform to find the best luxury fashion clothes for women. Its mission is summarized in bringing the best of international luxury fashion directly to the door of each client. With its intuitive online platform, which is updated every week with the latest arrivals, they assure customers of an exclusive, select and unique shopping experience, as if they were in a famous boutique. Although it was founded as a physical boutique in the city of Munich 30 years ago, in 2006 they made the pioneering leap to the online platform. This allowed them to position themselves as an exclusive luxury platform, and offer their fashion to more than 140 countries around the world, thanks to the almost 700 employees who work to position the customer at the center of their entire strategy.

They have more than 200 trusted luxury brands, exclusive collaborations of famous designers and also capsule collections for Mytheresa, ensuring the exclusivity of the garments once again. The Jimmy Choo, Saint Laurent, Loro Piana or Gucci brands stand out. About 1000 articles on average are incorporated into the platform every week, which are divided into categories within the web to facilitate their search and classification [31]

Its competitive advantage lies mainly on its customer service and complete orientation, with the aim of advising them and helping them achieve the closet of their dreams. They offer personalized attention from their attraction to the company, through exclusive newsletters to each type of client according to the way of dressing and expressing themselves. Then, they accompany them throughout the purchase process and advise them with their favorite models, sizes and combination of garments in order to solve their possible doubts, regardless its importance.

Moreover, they also offer a personal shopper service for loyal customers with high purchasing power and lack of time. For this reason, customer retainment is also a key feature for MyTheresa success, ensuring profitability and sustainability of the brand.

Customer care service is available in 13 different languages, 24 hours a day throughout the week. In addition, they offer a fast delivery that adds value to the demanding customers of the 
company (1 day in Germany) and free returns within 30 days after purchase, without forgetting the cybersecurity and protection of the online purchases of its customers.

\section{Comparative analysis and key factors}

In the following table, we can appreciate the differences and similarities between both case studies, the e-commerces Zalando and Mytheresa.

Regarding the similarities, as it was already commented before both companies belong to the fashion sector, their channel of commerce is online (e-commerce), and both are German companies and follow a client-orientation strategy. In this way, both enterprises offer augmented value to their clients thanks to their client-relationship management in social networks. However, regarding its way to compete, they highlight different things in their relationship with the clients.

Whilst Zalando focuses on a public from 18 years old to 40, with a wide range in which it concerns to purchase power, Mytheresa focuses on a target that goes from 30 to 45 years old, and with a high purchasing power. Therefore, Zalando focuses its strategy in customer attraction and lead conversion, in order to achieve higher sales volume. They are able to do so due to a stock of wide range of products and capabilities.

\begin{tabular}{|c|c|c|}
\hline & Zalando & Mytheresa \\
\hline \multirow[t]{5}{*}{ Differences } & $\begin{array}{l}\text { Target age from } 18 \\
\text { to } 40 \text { years old } \\
\text { with average } \\
\text { purchasing power }\end{array}$ & $\begin{array}{l}\text { Target age from } 30 \text { to } \\
45 \text { years old with high } \\
\text { purchasing power }\end{array}$ \\
\hline & $\begin{array}{l}\text { Client-orientation } \\
\text { strategy focused in } \\
\text { customer attraction }\end{array}$ & $\begin{array}{l}\text { Client-orientation } \\
\text { strategy focused in } \\
\text { customer retention }\end{array}$ \\
\hline & $\begin{array}{l}\text { Stock of a wide } \\
\text { range of products }\end{array}$ & $\begin{array}{l}\text { No stock, exclusive } \\
\text { products }\end{array}$ \\
\hline & $\begin{array}{l}\text { No personalized } \\
\text { attention in social } \\
\text { media }\end{array}$ & $\begin{array}{l}\text { Personalized attention } \\
\text { in social media }\end{array}$ \\
\hline & $\begin{array}{l}\text { Newsletter by } \\
\text { seasons and trends }\end{array}$ & $\begin{array}{l}\text { Newsletter by types of } \\
\text { products and trends in } \\
\text { haute couture }\end{array}$ \\
\hline \multirow[t]{3}{*}{ Similarities } & \multicolumn{2}{|c|}{ Fashion \& retail sector } \\
\hline & \multicolumn{2}{|l|}{ German e-commerce } \\
\hline & \multicolumn{2}{|c|}{ Long term client-orientation strategy } \\
\hline
\end{tabular}

On the other hand, Mytheresa focuses its entire strategy in client retention and increase of customer loyalty. For this reason, they do personalized communication and attention to their clients according their tastes, past purchases and interest thanks to online data, offering always the latest exclusive products.

\section{CONCLUSIONS}

In our changing and volatile environment, the changes in business models and shifts to e-commerce are just the beginning. Concepts as 'fashnology' [32] are each time more common among practitioners and academics trying to define the active role that technology plays in fashion sector.

Though the use of technology in e-business is crucial, especially the internet, the presentation and exposure of products in the websites represents a type of knowledge that can be vital for B2C. For this reason, companies continuously challenge themselves and try to adapt their strategies to the current context.

As it has been commented along the last sections of the present paper, Zalando and Mytheresa are two examples of successful retail e-commerces that competing with different strategies, share a client-orientation in its whole structure.

According what it was stated in the literature [20][21], both case studies employ social media marketing as the outstanding method for communicating with clients and receiving their feedback. Client-orientation based businesses, therefore bases their key strategy in branding and reputation management, customer satisfaction and enhancement of offered value. 


\section{REFERENCES}

[1] Grimaldi, D., Fernandez, V., \& Carrasco, C. (2019). Heuristic for the localization of new shops based on business and social criteria. Technological Forecasting and Social Change, 142(July 2018), 249-257.

[2] Hjort, K., \& Lantz, B. (2016). The impact of returns policies on profitability: A fashion e-commerce case. Journal of Business Research, 69(11), 4980-4985.

[3] Boons, F., \& Bocken, N. (2018). Towards a sharing economy Innovating ecologies of business models. Technological Forecasting and Social Change, 137(December 2017), 40-52.

[4] Scridon, M. A., Achim, S. A., Pintea, M. O., \& Gavriletea, M. D. (2019). Risk and perceived value: antecedents of customer satisfaction and loyalty in a sustainable business model. Economic Research-Ekonomska Istraživanja, 32(1), 909-924

[5] eMarketer, 2017. A brief overview of the global e-commerce market. eMarketer, July 14.

[6] Đurić, G., Todorović, G., Đorđević, A., \& Borota Tišma, A. (2019). A new fuzzy risk management model for production supply chain economic and social sustainability. Economic Research-Ekonomska Istraživanja, 32(1), 1697-1715.

[7] Baker, J., Ashill, N., Amer, N., \& Diab, E. (2018). The internet dilemma: an exploratory study of luxury firms' usage of internet-based technologies. Journal of Retailing and Consumer Services, 41, 37-47.

[8] Amit, R and Zott, C (2001). Value Creation in e-business. Strategic Management Journal, 22, 493-520.

[9] Devaraj, S., Krajewsky, L and Wei, J. C. (2007). Impact of e-Business technologies on operational performance: The role of production information integration in the supply chain. Journal of Operations Management, 25(6), 1199-1216.

[10] Clement, J. (2019). E-commerce worldwide - Statistics \& Facts. Statista. Retrieved from https://www.statista.com/topics/871/online-shopping/ Consulted: 6/2/2020

[11] Statista (2020). Retail e-commerce sales worldwide from 2014 to 2023. Retrieved from https://www.statista.com/statistics/379046/worldwideretail-e-commerce-sales/

[12] Amankwah-Amoah, J., \& Hinson, R. E. (2019). Contextual influences on new technology ventures: A study of domestic firms in Ghana. Technological Forecasting and Social Change, 143(December 2018), 289-296. https://doi.org/10.1016/j.techfore.2019.01.019

[13] E-commerce Europe Position paper (2018). Retrieved from: https://www.ecommerce-europe.eu/wpcontent/uploads/2018/12/ECOM-Updated-Position-Paper-on-P2Bupdate-November-2018.pdf

[14] Uimonen, T. (2015). Finnish man's identity work through luxury fashion discourses.

[15] Brady, Michael K., and J. Joseph Cronin Jr. "Customer orientation: Effects on customer service perceptions and outcome behaviors." Journal of service Research 3.3 (2001): 241-251.

[16] Chen, S. C., \& Lin, C. P. (2019). Understanding the effect of social media marketing activities: The mediation of social identification, perceived value, and satisfaction. Technological Forecasting and Social Change, 140(November 2018), 22-32.

[17] Van Dolen, W.M., Dabholkar, P.A., De Ruyter, K., 2007. Satisfaction with online commercial group chat: the influence of perceived technology attributes, chat group characteristics, and advisor communication style. J. Retail. 83 (3), 339-358.

[18] Lovelock, C.H., 2001. Services Marketing, 4th ed. Prentice Hall International.

[19] Jin, B., Jung, S., \& Jeong, S. W. (2018). Dimensional effects of Korean SME's entrepreneurial orientation on internationalization and performance: the mediating role of marketing capability. International Entrepreneurship and Management Journal, 14(1), 195-215.

[20] Kumar, V, Pradhan, P. (2016) 'Reputation management through online feedbacks in e-business environment', International Journal of Enterprise Information Systems (IJEIS), Vol. 12, No. 1, pp.21-37.

[21] Ayodeji, O. G., \& Kumar, V. (2019). Social media analytics: a tool for the success of online retail industry. International Journal of Services Operations and Informatics, 10(1), 79-95.

[22] Dann, S. (2010). Redefining social marketing with contemporary commercial marketing definitions. Journal of Business research, 63(2), 147-153.

[23] Elena, C. A. (2016). Social Media-A strategy in developing customer relationship management. Procedia Economics and Finance, 39, 785-790.

[24] Ali, I. (2019). Personality traits, individual innovativeness and satisfaction with life. Journal of Innovation \& Knowledge, 4(1), 38-46.

[25] Hwangbo, H., Kim, Y. S., \& Cha, K. J. (2018). Recommendation system development for fashion retail e-commerce. Electronic Commerce Research and Applications, 28, 94-101.

[26] Nordqvist, S., \& Frishammar, J. (2019). Knowledge types to progress the development of sustainable technologies: a case study of Swedish demonstration plants. International Entrepreneurship and Management Journal, 15(1), 75-95.

[27] Alshanty, A. M., \& Emeagwali, O. L. (2019). Market-sensing capability, knowledge creation and innovation: The moderating role of entrepreneurial-orientation. Journal of Innovation \& Knowledge, 4(3), 171-178.

[28] García-Fernández, J., Gálvez-Ruiz, P., Vélez-Colon, L., OrtegaGutiérrez, J., \& Fernández-Gavira, J. (2018). Exploring fitness centre consumer loyalty: differences of non-profit and low-cost business models in Spain. Economic Research-Ekonomska Istraživanja, 31(1), 1042-1058.

[29] Fionda, A. M., \& Moore, C. M. (2009). The anatomy of the luxury fashion brand. Journal of brand Management, 16(5-6), 347-363.

[30] Zalando, (2020). Retrieved from: https://corporate.zalando.com/en/company/zalando-at-a-glance Consulted: 6/2/2020.

[31] Mytheresa (2020). Retrieved from: https://www.mytheresa.com/ende/women.html Consulted: 8/2/2020

[32] Herz, M., \& Rauschnabel, P. A. (2019). Understanding the diffusion of virtual reality glasses: The role of media, fashion and technology. Technological Forecasting and Social Change, 138(October 2017), 228242. 